\title{
Литература
}

1. Аллахвердов М.В. Принцип проверяемости имплицитных теорий // Вестник Санкт-Петербургского университета. Серия 12. Социология. 2011. №. 3. C.14-19.

2. Бабаева Ю.Д., Березанская Н.Б., Васильев И.А., Войскунский А.Е., Корнилова Т.В. О вкладе О.К. Тихомирова в методологию, теорию и экспериментальную практику психологической науки // Методология и история психологии 2009. Т.4. №4. С. 9-27.

3. Доминяк В.И., Марарица Л.В. Имплицитная диагностика ценностей личности: перспективы и ограничения. - Сборник научных статей по материалам I (IV) Международной научно-практической конференции, проходившей в МГППУ с 23 по 25 апреля 2013 года / Под общей ред. М.Г. Ковтунович. М.: МГППУ, 2013. С.161-174.

4. Павлова Е.М. Имплицитные теории и самооценка креативности в структуре самосознания личности // Психология. Журнал Высшей школы экономики. 2014. Т.11. №.4. С.75-94.

5. Свешникова Е.Н. Адаптация в виртуальная среде как фактор творческой реализации у подростков. Психологические исследования, 2016, 9(45), 4. http://psystudy.ru

6. Токарева Г.В., Дорфман Л.Я. Имплицитные процессы и их исследование в Западной психологии //Вестник Южно-Уральского государственного университета. Серия: Психология. 2014. Т. 7. №. 1. С.17-27.

7. Федосина С.С. К 60-летию существования понятия «Имплицитная теория» в психологической науке //Вестник Пермского университета. Философия. Психология. Социология. 2014. №. 3 (19). С.83-93.

8. Яньшин П.В. Экспериментальная парадигма косвенного исследования эмоциональных установок через непроизвольную задержку моторных p011 еакций // Поволжский педагогический вестник. 2015. №. 3 (8). С.40-47.

9. Fiske S. T., Gilbert D. T., Lindzey G. Handbook of social psychology. Vol.1 John Wiley \& Sons, 2010.

10. Greenwald A.G., McGhee D.E., Schwartz J. L.K. Measuring individual differences in implicit cognition: the implicit association test //Journal of personality and social psychology. 1998. Vol. 74. №. 6. P. 1464-1480

11. Runco M.A., Johnson D.J., Bear P.K. Parents' and teachers' implicit theories of children's creativity // Child Study Journal. Vol.23. №2. 1993. P.91-113

12. Sternberg R.J. Implicit theories of intelligence, creativity, and wisdom // Journal of personality and social psychology. 1985. Vol. 49. № 3. P. 607-627

13. Wegner, D. M., Vallacher, R. R. Implicit psychology: An introduction to social cognition. New York: Oxford University Press. 1977.

\section{О МЕХАНИЗМАХ ПСИХОЛОГИЧЕСКОЙ ЗАЩИТЫ МАТЕРЕЙ}

\section{Базалева Л.А.}

Семья - это важнейший из феноменов, сопровождающий человека в течение всей его жизни. Значимость семьи и ее влияния на личность привлекает 
внимание многих специалистов разных школ и направлений. Семья занимает одно из ведущих мест среди общечеловеческих ценностей. Однако в жизни это не всегда и не всеми осознается в достаточной степени. Только разрушив семейный очаг, мы начинаем задумываться о том, где и какие ошибки были допущены, почему нам не удалось сберечь то, что мы вряд ли сможем воссоздать в том же виде вновь.

Хотя каждый человек более или менее отчетливо сознает, что его семейное счастье - в его руках, очень немногие при этом задумываются о благополучии своих детей. Отсутствие полноценного образца для внутрисемейной социализации почти всегда ведет к ухудшению в отношениях с детьми, к определенным нарушениям в психическом и личностном развитии ребенка.

В наше время количество одиноких матерей, к сожалению, неумолимо растет, поэтому важно знать, какие трудности социального и психологического порядка ожидают одиноких матерей и их детей.

На наш взгляд, наиболее интересна и одновременно наименее изучена проблема влияния личности матери на характер отношений с детьми.

Жизнь женщины после рождения ребенка кардинально меняется, особенно это заметно, когда семья неполная и отец не принимает участие в воспитании ребенка и не помогает финансово. В таком случае все обязанности по дому, а также содержание семьи падает на плечи женщины. Пытаясь выполнять в семье функциональные обязанности обоих родителей, мать стремится следовать в своем поведении тем социально-психологическим ролям, которые обычно разделены между мужчиной и женщиной. Поэтому она зачастую, руководствуясь искаженным представлением о ролевом поведении настоящего мужчины в семье, становится негибкой, излишне принципиальной, авторитарной и властолюбивой личностью, не склонной к компромиссам, принимает на себя единоличную ответственность за ребенка. Вследствие подобного «ролевого замещения» она утрачивает те исконно женские черты, которые ассоциируются с добротой, состраданием и эмоциональной отзывчивостью. Подобный конфликт между социально-психологическими ролями матери и отца в семье чутко улавливаются детьми, что не может не отразиться на отношениях с ними.

В то же время, адаптация к такому образу жизни, а также процесс роста и развития личности предполагает неизбежность возникновения механизмов психологической защиты матери. С одной стороны, возникновение механизмов психологической защиты стабилизирует эмоциональное состояние, с другой стороны, мешает реально оценить свои возможности и адекватно реагировать на фрустрирующую ситуацию. Именно в такой ситуации, находится мать, воспитывающая детей одна. В связи с этим, нам кажется интересным посмотреть специфику механизмов психологической защиты у матерей в полных семьях и одиноких матерей, а также влияние механизмов на отношения с детьми.

Проблема изучения механизмов психологической защиты достаточно хорошо рассматривается в отечественной и зарубежной психологии. Но к сожалению, исследование специфики механизмов психологической защиты в 
отношениях с детьми немногочисленны и в большинстве своем имеют описательно-теоретический характер.

Таким образом, недостаточная изученность механизмов психологической защиты матерей-одиночек в отношениях с детьми обуславливают актуальность данного исследования.

Цель исследования- выявить специфику механизмов психологической защиты одиноких матерей.

Мы разработали анкету, по результатам которой получили данные о социальном статусе испытуемых, о наличии/отсутствии помощи со стороны мужа или других членов семьи. На основе полученных данных мы сформировали выборку, включающую две равные независимые группы испытуемых:

1. Экспериментальная группа, состоящая из одиноких матерей учащихся 2-го, 3-го, 4-го классов. Объем выборки - 32 человека.

2. Контрольная группа, включающая матерей из полных семей учащихся 2-го, 3-го, 4-го классов. Объем выборки - 32 человека.

Для проведения обследования мы использовали следующие диагностические методики:

$\checkmark$ методика «Индекс жизненного стиля» с целью выявления ведущего механизма психологической защиты;

$\checkmark$ «Методика диагностики родительского отношения А.Я.Варга и В.В.Столина» с целью диагностики особенностей родительского отношения;

$\checkmark$ методика «PARI» с целью изучения отношения матерей к разным сторонам семейной жизни.

В результате проведенного психодиагностического исследования были получены первичные эмпирические данные по всем в соответствии с целью данной работы методикам.

Полученные эмпирические данные свидетельствуют о том, что распределение частот встречаемости механизмов психологической защиты в основной и контрольной выборках не имеют различий.

Но можно отметить следующее: одинокие матери используют в повседневной жизни все восемь механизмов психологической защиты. Однако наиболее часто они прибегают к такому механизму как регрессия (в 25\% случаев). То есть для их поведения характерно возвращение к примитивным, ранним, связанным с детством, формам реагирования и типам поведения; переход на предшествующие уровни психического развития и актуализация успешных в прошлом способов реагирования. Меньше всего одинокие матери пользуются в жизни компенсацией $(3,1 \%)$.

Матери из полных семей используют семь механизмов психологической защиты из восьми. То есть такой механизм как компенсация не используется ими вообще. Наиболее часто в своей жизни матери из полных семей прибегают к такому механизму психологической защиты как реактивное образование (31,2\%). Реактивное образование - замена неприемлемых тенденций на прямо противоположные (так называемая инверсия желаний), когда люди могут скрывать от самих себя мотив собственного поведения за счет его подавления 
сознательно поддерживаемым мотивом противоположного типа. Например, бессознательная неприязнь к ребенку может выражаться в нарочитом, контролирующем внимании к нему. И, также как и одинокие матери, к регрессии (31,2\%). Наименее часто они используют вытеснение $(6,2 \%)$ и интеллектуализацию $(6,2 \%)$.

Матери из полных семей чаще принимают своего ребенка таким, какой он есть, они уважают его индивидуальность, симпатизируют ему. Стремятся проводить много времени с ребенком, одобряют его интересы и планы. Матери из полных семей больше стараются во всем помочь ребенку, высоко оценивают его интеллектуальные и творческие способности, испытывают чувство гордости за своего ребенка, поощряют его инициативу и самостоятельность, доверяют. Также матери из полных семей чаще используют в отношениях с детьми такой стиль семейного воспитания как симбиоз. Это значит, что они ощущают себя единым целым с ребенком, стремятся удовлетворить все его потребности, оградить от всех трудностей и неприятностей жизни, постоянно ощущают тревогу за ребенка, считают его маленьким и беззащитным. Тревога родителя повышается, когда ребенок начинает автоматизироваться в силу обстоятельств.

Одинокие матери используют чаще такой стиль семейного воспитания как авторитарная гиперсоциализация, то есть в родительском отношении данного родителя отчетливо просматривается авторитаризм. Матери требуют от ребенка безоговорочного послушания и дисциплины. Они стараются во всем навязать ребенку свою волю, не в состоянии стать на его точку зрения. За проявления своеволия ребенка сурово наказывают. Мать пристально следит за социальными достижениями ребенка, его привычками, мыслями, чувствами. И очень часто одинокие матери воспринимают своего ребенка как маленького неудачника, стремятся приписать ему личную и социальную несостоятельность. Мать видит ребенка младшим по сравнению с реальным возрастом. Интересы, увлечения, мысли и чувства ребенка кажутся ей детскими, несерьезными. Одинокие матери не доверяют своим детям, досадую на его неуспешность и неумелость. В связи с этим они стараются оградить ребенка от трудностей жизни и строго контролировать его действия.

Так, например, матери из полных семей более удовлетворены своей семейной жизнью, чем одинокие матери. В отношениях с детьми у матерей из полных семей наблюдается тесный эмоциональный контакт. То есть между матерью и ребенком партнерские отношения, мать развивает активность ребенка.

Одинокие матери чаще испытывают по отношению к ребенку раздражительность, вспыльчивость, чаще бывают суровы. Излишне концентрируясь на ребенке, они проявляют чрезмерную заботу, подавляют волю, агрессивность, а также чрезмерно вмешиваются в мир ребенка.

C помощью программы Excel мы провели статистический анализ с целью выявления значимых различий в использовании механизмов психологической защиты матерями-одиночками и матерями из полных семей. 
Мы выявили, что статистически значимых различий в использовании механизмов психологической защиты одинокими матерями и матерями из полных семей нет, но существуют определенные различия в использовании стиля родительского отношения в контрольной и экспериментальной группах.

Одинокие матери, в отличие от матерей из полных семей, склонны использовать по отношению к своим детям такой стиль семейного воспитания как маленький неудачник. Статистически значимые различия выявлены на уровне 0,005 .

У одиноких матерей, в отличие от матерей из полных семей, существует тенденция к излишней концентрации на ребенке. Статистически значимые различия выявлены на уровне 0,005 .

Однако, мы считаем возможным привлечение дополнительных статистических процедур для выявления связей механизмов психологической защиты и параметров детско-родительских отношений.

Для выявления таких связей мы использовали корреляционный анализ Пирсона, получив следующие данные.

У одиноких матерей существуют определенные корреляционные связи между показателями детско-родительских отношений и механизмов психологической защиты. А именно: механизм психологической защиты отрицание находится в положительной корреляционной связи с таким параметром детско-родительского отношения как симбиоз $(0,37)$ и маленький неудачник $(0,33)$. «Регрессия» находится в отрицательной корреляционной связи с отношением к семейной роли (-0,53). «Проекция» положительно коррелирует с излишней концентрацией $(0,33)$ и отрицательно с кооперацией (0,54). «Замещение» отрицательно коррелирует с эмоциональной дистанцией ($0,33)$.

У матерей из полных семей другие корреляционные связи между параметрами детско-родительских отношений и механизмами психологической защиты, а именно: механизм психологической защиты отрицание находится в положительной корреляционной связи с эмоциональной дистанцией $(0,41)$ и в отрицательной корреляционной связи с кооперацией $(0,38)$. «Вытеснение» отрицательно коррелирует с эмоциональным контактом $(-0,40)$. «Регрессия» находится в положительных корреляционных связях с эмоциональной дистанцией $(0,35)$ и с авторитарной гиперсоциализацией $(0,39)$. «Замещение» положительно коррелирует с излишней концентрацией на ребенке $(0,44)$ и отрицательно с эмоциональным контактом (-0,61). «Интеллектуализация» отрицательно коррелирует с отношением к семейной роли $(-0,39)$.

В итоге проведенного корреляционного анализа эмпирических значений механизмов психологической защиты и параметров детско-родительского отношения у матерей-одиночек и матерей из полных семей была выявлена связь этих показателей на уровне статистической значимости $(\mathrm{p}=0,005)$.

Анализ эмпирических данных показал наличие различных корреляционных связей между показателями механизмов психологической защиты и параметрами детско-родительских отношений в контрольной и экспериментальной группах. 
Таким образом, в результате применения методов математикостатистической обработки были получены данные, которые могут подвергаться дальнейшему психологическому анализу и интерпретации.

Подводя итог по работе в целом, можно отметить, что анализ основных литературных источников по проблеме механизмов психологической защиты личности, показал:

Защитные механизмы имеют общие свойства:

$\checkmark$ они действуют в подсознании, индивид не осознает, что с ним происходит;

$\checkmark$ они отрицают, искажают или фальсифицируют действительность;

$\checkmark$ они действуют в ситуации конфликта, фрустрации, психотравмы, стресса.

Цель психологической защиты - снижение эмоциональной напряженности и предотвращение дезорганизации поведения, сознания и психики в целом.

Механизмы психологической защиты обеспечивают регуляцию, направленность поведения, редуцируют тревогу и эмоциональное поведение.

В своей работе нам было интересно посмотреть влияние механизмов психологической защиты матерей на детско - родительские отношения.

Родительские отношения - это система разнообразных чувств к ребёнку, поведенческих стереотипов, практикуемых в общении с ним, особенностей восприятия и понимание характера и личности ребёнка, его поступков; это процесс и результат индивидуального отражения семейных связей, опосредующие внутреннюю и внешнюю активность родителей и детей в их совместной деятельности.

В неполной семье одинокий родитель сталкивается с необходимостью приспосабливаться к многочисленным изменениям, происходящим в его жизни, к новым моделям взаимодействия с собственным ребенком или детьми, потому что ему одному приходится совмещать функции обоих родителей, к новым взаимоотношениям с окружающим миром и другими людьми.

В условиях российской действительности неполная семья чаще всего состоит из матери с ребенком или несколькими детьми, то есть является «материнской». Поэтому в центре нашего внимания механизмы психологической защиты матерей в отношениях с детьми.

В результате эмпирического исследования мы увидели специфику механизмов психологической защиты одиноких матерей и выявили их влияние на детско-родительские отношения.

Полученные эмпирические данные позволили провести сравнение механизмов психологической защиты одиноких матерей и матерей из полных семей. Наиболее выраженными механизмами психологической защиты у матерей из полных семей и одиноких матерей являются регрессия и реактивное образование.

Одинокие матери гораздо чаще воспринимают своих детей как маленьких неудачников, и у них существует тенденция излишне концентрироваться на своих детях. 
В заключении хочется отметить, что интересно было бы рассмотреть механизмы психологической защиты отцов, сравнить их с психологической защитой матерей. А также выявить специфику влияния механизмов психологической защиты отцов на детско-родительские отношения.

\section{Литература}

1. Авдеева Н.Н., Хаймовская Н.А. Зависимость типа привязанности ребенка ко взрослому от особенностей их взаимодействия // Психологический журнал. - 1999. Т.20. №1. С.39-48.

2. Базалева Л.А. Безопасность или психологическая опасность в содержании отношений в системе «мать-дитя»// Психология безопасности и психологическая безопасность: проблемы взаимодействия теоретиков и практиков Сборник материалов VII Всероссийского научного семинара, г. Сочи, 9-10 сентября 2016 г. / Министерство образования РФ; Соч. гос. ун-т; Соц.-пед. ф-т СГУ; Под ред. И.Б. Шуванова, В.В. Знакова, З.И. Рябикиной, Г.Ю. Фоменко, В.Ф. Енгалычева, Ю.Э. Макаревской. — Сочи: СГУ, 2016. 168 c. C. $6-13$

3. Базалева Л.А. Личность женщины и материнство //Человек. Искусство. Вселенная. научно-практический журнал. - Центр развития человека, 2015. № 1. C. 114-121.

4. Лунякова Л.Г. О современном уровне жизни семей одиноких матерей // Социологические исследования, - 2001 №8, С. 86-99.

5. Целуйко В.М. Вы и ваши дети. Психология семьи. - Ростов н/Д: «Феникс», 2004. - 448c. (Серия «Психологический практикум»)

\section{О СОВЕРШЕНСТВОВАНИИ ПРОЦЕДУРЫ ПСИХОЛОГИЧЕСКОГО ЭКСПЕРИМЕНТА}

Балин В.Д.

В одном из недавних исследований было показано, что воспроизводимость результатов психологического эксперимента весьма низка. (Science 28 Aug 2015;Vol. 349). Что же является причиной такой низкой воспроизводимости? Ясно, что авторы исследований учитывают и описывают не все условия, в которых производилось психологическое исследование, многие вещи считаются само собой разумеющимися, но на поверку таковыми не являются. Очевидно, что совершенствовать психологическое исследование и эксперимент можно на все его этапах. Мы в данной статье рассмотрим в основном влияние двух факторов психологического исследования на его результаты: 1.Особенности понимания испытуемым инструкции к заданию и сути самой экспериментальной ситуации. 2. Особенности экспериментатора как важного участника экспериментальной ситуации.

1. Понимание инструкции. $\mathrm{B}$ руководствах по экспериментальной психологии проблема понимания испытуемым инструкции обычно упоминается вскользь, как нечто само собой разумеющееся. Если эксперимент проводится в рамках общей психологии, когда используются термины только одного уровня обобщенности, это можно считать допустимым. Однако 